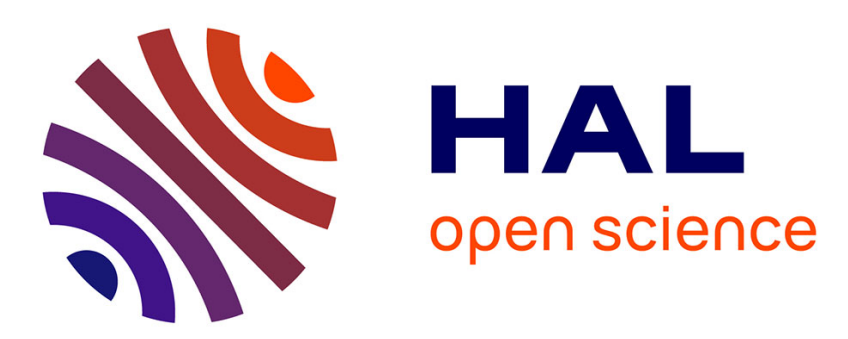

\title{
Low pre-death growth rates of oak (Quercus robur L.)-Is oak death a long-term process induced by dry years?
}

\author{
Andersson, Milberg, Bergman
}

\section{To cite this version:}

Andersson, Milberg, Bergman. Low pre-death growth rates of oak (Quercus robur L.)-Is oak death a long-term process induced by dry years?. Annals of Forest Science, 2011, 68 (1), pp.159-168. 10.1007/s13595-011-0017-y . hal-00930740

\section{HAL Id: hal-00930740 \\ https://hal.science/hal-00930740}

Submitted on 1 Jan 2011

HAL is a multi-disciplinary open access archive for the deposit and dissemination of scientific research documents, whether they are published or not. The documents may come from teaching and research institutions in France or abroad, or from public or private research centers.
L'archive ouverte pluridisciplinaire HAL, est destinée au dépôt et à la diffusion de documents scientifiques de niveau recherche, publiés ou non, émanant des établissements d'enseignement et de recherche français ou étrangers, des laboratoires publics ou privés. 


\title{
Low pre-death growth rates of oak (Quercus robur L.)- Is oak death a long-term process induced by dry years?
}

\author{
Marie Andersson • Per Milberg • Karl-Olof Bergman
}

Received: 26 January 2010 / Accepted: 3 June 2010 / Published online: 17 February 2011

(C) INRA and Springer Science+Business Media B.V. 2011

\begin{abstract}
- Background and purpose A complex interplay between biotic and abiotic factors is believed to be responsible for several oak declines in pedunculate oak (Quercus robur L.). This study aims to clarify the temporal process of oak declines, as well as identifying individual tree and environmental variables that affects growth rate and that may increase the risk of mortality. The study was performed in southern Sweden at three sites.

- Findings Cross-dating revealed that most trees had died during the last decade and that the growth rates of the dead oaks were affected long before death. Averaged growth chronologies of dead and control trees reaching 150 years back in time illustrated an excellent match up until around 1992, when a severe drought occurred after which the dead trees started to express reduced growth. Precipitation the previous year during August-September and during March-June this current year was of significant importance for oak growth. Site-specific results that showed that dead trees: included fewer small-sized trees, grew on non-clay soils, were more likely to have shelf fungus and cavities and were exposed to less sunshine.

- Conclusion The results support the theories that oak mortality is a long process that may be induced decades before the actual death.
\end{abstract}

Keywords Dendrochronology · Growth depression · Oak decline Extreme weather Pointer year

Handling Editor: Gilbert Aussenac

M. Andersson · P. Milberg • K.-O. Bergman $(\bowtie)$

IFM Biology, Division of Ecology, Linköping University,

SE-581 83, Linköping, Sweden

e-mail: karl-olof.bergman@liu.se

\section{Introduction}

Changes in land use and management strategies during the last century have reduced the areas of old-growth temperate deciduous forests in Europe to a small fraction of its original distribution (Hannah et al. 1995). This has had a severe impact on species diversity. Old large-diameter deciduous trees have been identified as the most important element contributing to species diversity in forested ecosystems (Davies et al. 2008). In order to develop appropriate management strategies aimed at preserving biodiversity connected to these areas, there is a need to better understand the fundamental dynamics structuring forest stands. In addition to regeneration and growth, tree mortality is one of the major processes causing structural and compositional change. However, the actual causes of tree mortality are difficult to identify with certainty, because several direct and indirect factors tend to act together over long periods of time (Thomas et al. 2002, Thomas 2008).

Occurrences of oak (Quercus spp.) declines have been recorded in many parts of Europe during the past three decades (Thomas et al. 2002). Several attempts have been made in order to identify factors triggering the onset and outbreak of the declines. However, no consensus has yet emerged. Reports of declines in European oak stands suggest that factors responsible for the tree mortality include summer droughts (Dreyer 1994, cited by Thomas et al. 2002) and winter or spring frosts (Thomas and Hartmann 1996; Barklund 2002). Other possible factors are site conditions (Thomas and Hartmann 1996; Thomas et al. 2002), root pathogens of the genus Phytophthora (Jung et al. 2000; Jönsson et al. 2005), and direct and indirect effects of nutrient imbalances (Thomas and Blank 1996; Kinney et al. 1997). A conceptual model describing the interactions of 
biotic and abiotic factors involved in the emergence of oak declines included the factors insect defoliation, summer drought, and winter/spring as crucial (Thomas et al. 2002).

In Sweden, oak (Quercus robur L.) declines have been reported from various locations within its distribution range since 1987 (Barklund 2002). Oaks are of particular importance for nature conservation in Sweden, since they support species diversity by providing essential habitats for numerous species found on the national Red List (Drobyshev et al. 2008a). A dendrochronological study of oak stands performed in southern Sweden showed a significant increase in the mortality in the middle and late 1990 s, believed to have been caused mainly by a severe spring and summer drought in 1992 (Drobyshev et al. 2007). A time lag in the mortality-inducing event and the actual death of the tree is supported by several studies (Pedersen 1998; Marçais and Caël 2001; Haavik et al. 2008), emphasizing the importance of using a wide time perspective when analyzing factors causing tree declines. To be able to clarify the mortality process, general factors affecting growth are also important to understand. General pre-death growth patterns can give valuable information of which factors that may cause a reduction of growth rate and contribute to sensitivity to other factors that may cause death (Drobyshev et al. 2007).

This study was performed in an area holding one of the highest concentrations of old oaks in northern Europe (Ranius et al. 2009). By comparing environmental and tree data of living and dead oaks and using core samples of dead and living oaks the main objective was to: (1) study the correlation between growth rate, environmental factors (e.g., precipitation and temperature), and tree characteristics (e.g., diameter) and identify possible extreme years (pointer years), (2) determine the temporal process of the oak mortality, (3) compare pre-death growth rates of dead oaks with living trees to clarify how growth rate are affected before death.

\section{Methods}

\subsection{Study area}

Data were collected from three sites within the county of Östergötland, south-eastern Sweden: Tinnerö, Norrköping, and Sturefors. All sites were parts of grazed, oak-dominated nature reserves, representing one of the few landscapes in northern Europe still holding high densities of old oaks (Ranius et al. 2009). Choosing sites within the boundaries of nature reserves minimized the influence of forest management, such as removal of dead trees. The region has an annual precipitation of 500-700 mm and a mean temperature of between -2 and $-4^{\circ} \mathrm{C}$ in January and around $16^{\circ} \mathrm{C}$ in July (Vedin 2004).

\subsection{Tree and environmental variables}

All dead, standing oaks with a diameter $>25 \mathrm{~cm}$ at breast height were localized and sampled at the three sites. A grid system covering the whole area at each site was used for selecting living trees to act as a control. In total, 216 dead and 335 living oaks were sampled (Table 1). For each individual tree, the circumference, depth of bark crevices, crown silhouette, and the presence/absence of shelf fungus and cavities were recorded. The circumference of the trees was measured at breast height (130 $\mathrm{cm}$ above ground), as was the depth of the bark crevices, which was calculated as the average of four samples taken perpendicularly to each other, each representing the maximum depth of the crevices facing each particular direction. Three categories were used for describing the crown silhouette: open, closed, or intermediate (Glimskär et al. 2007). The shape of the crown silhouette gives a reflection of the long-term growing conditions of the tree, for which an open crown silhouette indicates a solitary tree, and a closed crown silhouette indicates a tree growing in a dense canopy. The presence/absence of shelf fungus (e.g., Polyporus spp.) was recorded, as well as the presence/absence, size, and location of tree cavities. Six categories were used for describing the cavities, taking both the circumference of the entrance hole and the estimated amount of wood mould into consideration. The location of the cavity was described as "at ground level" or "above ground".

Environmental variables investigated included soil moisture, soil type, cover of bare rock, and sun exposure. Soil moisture was expressed as one out of three categories: moist, mesic, and dry. The classification was done by identifying the dominating indicator plant growing in an area reaching from stem and $5 \mathrm{~m}$ outside the crown edge. Deschampsia cespitosa (L.) P. Beauv., Filipendula ulmaria (L.) Maxim., and Juncus spp. indicated moist soils, broadleaved grasses indicated mesic soils, and Festuca ovina L., Campanula rotundifolia L., Pilosella officinarum F. W. Schultz and Sch. Bip, and Anthoxanthum odoratum L. indicated dry soils. A rolling test where a moistened sample of soil is rolled in the hand to smallest diameter possible was used to determine the soil type (Esseen et al. 2007), which was divided into two categories; clay (roll thickness, $<3 \mathrm{~mm}$ ) and not clay (roll thickness, $>3 \mathrm{~mm}$ ). The percentage ground covered by bare rock was estimated in an area equalling the size of the tree crown. Sun exposure was calculated as the percentage ground area not covered by other trees (with a height of $>3 \mathrm{~m}$ ) in an area reaching from the trunk and $5 \mathrm{~m}$ outside the crown edge.

Data of individual tree and environmental variables were analyzed in SPSS 16.0. In order to detect differences between dead and control trees, the continuous data was analyzed using 
Table 1 Site properties and number of dead/control oaks selected for tree/environmental variables and core samples

Cross-dating was used for dating the dead trees

\begin{tabular}{|c|c|c|c|c|c|c|c|}
\hline & \multirow{2}{*}{$\begin{array}{l}\text { Location } \\
\text { (WGS84) }\end{array}$} & \multirow{2}{*}{$\begin{array}{l}\text { Area } \\
\text { (ha) }\end{array}$} & \multicolumn{2}{|c|}{ Variables } & \multicolumn{2}{|c|}{ Sampled cores } & \multirow{2}{*}{$\begin{array}{l}\text { Dated cores } \\
\text { Paired cores }\end{array}$} \\
\hline & & & Dead & Control & Dead & Control & \\
\hline Tinnerö & $58^{\circ} 23^{\prime} \mathrm{N}, 15^{\circ} 37^{\prime} \mathrm{E}$ & 113 & 122 & 194 & 40 & 40 & 26 \\
\hline Norrköping & $58^{\circ} 37^{\prime} \mathrm{N}, 19^{\circ} 10^{\prime} \mathrm{E}$ & 20 & 35 & 64 & 12 & 12 & 7 \\
\hline Sturefors & $58^{\circ} 20^{\prime} \mathrm{N}, 15^{\circ} 45^{\prime} \mathrm{E}$ & 4 & 59 & 77 & 20 & 20 & 14 \\
\hline All sites & - & 137 & 216 & 335 & 72 & 72 & 47 \\
\hline
\end{tabular}

the Kolmogorov-Smirnov two-sample test and the $\mathrm{Chi}^{2}$-test of independence was used for the categorical data.

\subsection{Core samples}

Core samples were taken from 72 dead and 72 living oaks, representing all sites, using a Swedish increment borer (Table 1). Each tree was cored twice at breast height, the cores taken perpendicularly to each other and, in general, $30 \mathrm{~cm}$ into the tree. The dead trees cored were randomly chosen out of all dead oaks within the sites. A pairwise design was used for selecting the control trees to minimize the environmental variability. The living oak growing closest to the sampled dead one, having approximately the same circumference, was selected. Furthermore, the resemblance of the surroundings was taken into consideration when choosing the control tree, particularly when several oaks within the same size range were obtainable. Once sampled, the cores were brought back to the laboratory and were left to air dry, before being mounted on wooden plates and polished with sandpaper no. 60/80, 120, 180, 240, and 320.

In order to clarify the temporal process of the oak mortality, tree ring growth patterns were analyzed using dendrochronological methods. The cores were scanned (Nashuatec MP C3500, 400 dpi) and measured in a Cybis CooRecorder 7.1., before being analyzed in Cybis CDendro 7.1. To minimize the risk of errors caused by missing or false rings, the original ring widths of two cores from each individual tree, having a correlation value of $\geq 0.5$, were averaged into one single tree ring series. Due to difficulties in identifying the tree rings of the entire core, or obvious differences caused by branch formations, a few exceptions to the correlation threshold were made.

Cross-dating was used to determine the specific year of death of the dead oaks (Wiles et al. 1996). To enable comparison of trees of varying age and growing conditions, all curves were detrended using a negative exponential curve. In order to enhance the high-frequency signals, primarily used when cross-dating, the curves were normalized using a moving average. A master chronology for each site was composed out of those control trees showing the highest intercorrelation values. To ensure correct dating, threshold values were generated by cross-dating all dead trees against a nonrelated curve, ${ }^{1}$ where all matches found represented a possible incorrect dating. Trees fulfilling two of the three threshold values generated, correlation $\geq 0.5, \mathrm{BNDiff} \geq 0.01$, TTest $\geq 4.5$, were considered to be accurately dated. The correlation value describes the relationship between the curves, the BNDiff presents the difference between the best and the next best match of the curves and the TTest is based on the correlation, but also takes the length of the overlap into consideration. In total, 47 pairs of dated dead and living trees were used for the forthcoming analyses.

Changes in growth over the years preceding death were analyzed using multiple chronological clustering (Legendre et al. 1985) using the software Brodgar 2.5.7 (www. brodgar.com), in which breakpoints common for the majority of the individual ring width series were detected over the last 44 years. Raw ring width series of dead trees were used to examine the length of a possible growth depression prior to death, and the yearly difference in growth between the dead and the control tree in each pair was used for detecting a common year representing the offset of the growth depression.

\subsection{Influence of weather factors}

Using continuous time series analysis for investigating the correlation of tree growth and weather variables normally results in a large amount of signal noise remaining unexplained, in general, caused by the influences of tree ring widths shaped by factors other than the weather. One way of getting around this problem is to concentrate the analysis only on those years in which the majority of the trees have pronounced wide or narrow tree ring widths occurring simultaneously. By doing so, the relationship of the growth and weather is enhanced, and the end result is less affected by signal noise (Heinrich et al. 2008). In the present study, a hierarchical classification system, consisting of five intensity classes, was used to calculate pointer

\footnotetext{
${ }^{1}$ The international tree-ring data bank. Satellite and Information Service (NOAA). Available at: ftp://ftp.ncdc.noaa.gov/pub/data/paleo/treering/ chronologies/europe/pola006.crn Accessed on 7 October 2008.
} 
years and their intensity values (Neuwirth et al. 2004). All raw tree ring widths were initially normalized, using a moving average based on the four adjacent tree rings, in order to generate the difference in growth of a single tree ring relative to its neighboring tree ring widths. Thereafter, the normalized values were expressed as intensity classes, with the maximum intensity class (5) reached for a difference greater than $80 \%$ and the minimum intensity class (1) reached for differences less than $20 \%$. Based on the intensity classes, pointer year intensity values $(I)$ were calculated using the formula (Neuwirth et al. 2004):

$I=\frac{100}{k n} \sum_{j=1}^{k} h_{j} i_{j}[\%]$

$k \quad$ Number of intensity classes

$n \quad$ Total number of trees

$h$ Number of trees with event

$i$ Intensity class of event year

Correlation analyses between pointer year intensity values and weather factors were performed using Pearson's correlation (using SPSS 16.0). Average monthly air temperature and the sum of monthly precipitation were obtained from Malmslätt meteorological station, located 5-45 km from the sampling sites. The weather factors were expressed as standard deviation units based on the long-term monthly mean for the period 1961-2007. The 20 most extreme pointer years were used for the correlation analyses, and for each selected pointer year, the weather was identified for the period of the previous year's August to current year's December.

\section{Results}

Data of individual trees and their surroundings were collected for 216 dead and 335 living oaks (Table 1). The diameter at breast height (DBH) ranged from $25-176 \mathrm{~cm}$, with a mean value of $60 \mathrm{~cm}$.

Core samples were taken from 72 dead and 72 living oaks, resulting in 47 accurately dated pairs of trees (Table 1). The total length of the master chronology, represented by a minimum of half the cores dated, covered the time period 1845-2008 (mean correlation between trees, expressed population signal, and signal-to-noise ratio was $0.333,0.947$, and 18.0 , respectively). The cores had an averaged ring width of $1.40 \mathrm{~mm}$ (range, $0.13-7.68 \mathrm{~mm}$ ).

\subsection{Tree and environmental variables}

In order to detect possible differences between the dead and control trees, individual tree and environmental variables were analyzed. When pooling all sites or studying Tinnerö exclusively, the size distribution (DBH) differentiated between the dead and the control trees (Table 2), with the dead trees being more concentrated to the central part of the size span (Fig. 1). In particular, the dead oaks included fewer small-sized trees, i.e., trees with a DBH of $25-40 \mathrm{~cm}$. Analyses of the depth of the bark crevices confirmed this general pattern (Table 2). The amount of bare rock enclosing the oak did not differ between the dead and control trees and neither did the soil type when pooling all sites (Table 2). In Tinnerö, however, a somewhat higher frequency of dead oaks grew on non-clay soils (Table 2). The impact of soil moisture differentiated among the sites (Table 2). In Tinnerö, there was a higher frequency of dead oaks growing on moist soils, while most of the dead oaks in Sturefors grew on mesic soils. No significant difference was detected when pooling all sites. Dead oaks were more likely to have shelf fungus and cavities when pooling all sites (Table 2). Compared with the other sites, oaks in Sturefors generally grew under more closed conditions. The dead oaks at Sturefors were exposed to less sunshine and had more closed crown silhouettes than the control trees (Table 2).

\subsection{Core samples}

Cross-dating showed that most trees died during the last decade, with two pronounced peaks in 2004 and 2006 (Fig. 2). Examining each site separately revealed that the peak in 2004 was represented mainly by data from Tinnerö, while the peak in 2006 could be devoted foremost to data from Sturefors. No distinct pattern in the frequency of dead oaks was observed for Norrköping. Averaged growth chronologies of dead and control trees reaching 150 years back in time illustrated an excellent match up until around 1992, after which the dead trees started to express reduced growth (Fig. 2). Two main breakpoints in the growth trend were detected at 1989 and 1992 when applying multiple chronological clustering on data expressing the yearly difference between dead and control tree ring widths $(\alpha=0.01)$. Averaged chronologies of both dead and control trees showed a particularly strong growth reduction in 20032004, after which a recovery of the control trees was observed over the following years (Fig. 2). When examining each site separately, Tinnerö and Sturefors showed trends applicable to the pattern described above. Norrköping, however, showed a distinct decrease in growth starting around 1991, but no particularly strong growth reduction during the time period 2003-2004.

Averaged raw chronologies of dead trees expressed on a time-prior-to-death scale, presenting each site separately, revealed that the general growth trend differed among the sites, with trees from Tinnerö expressing an overall higher 


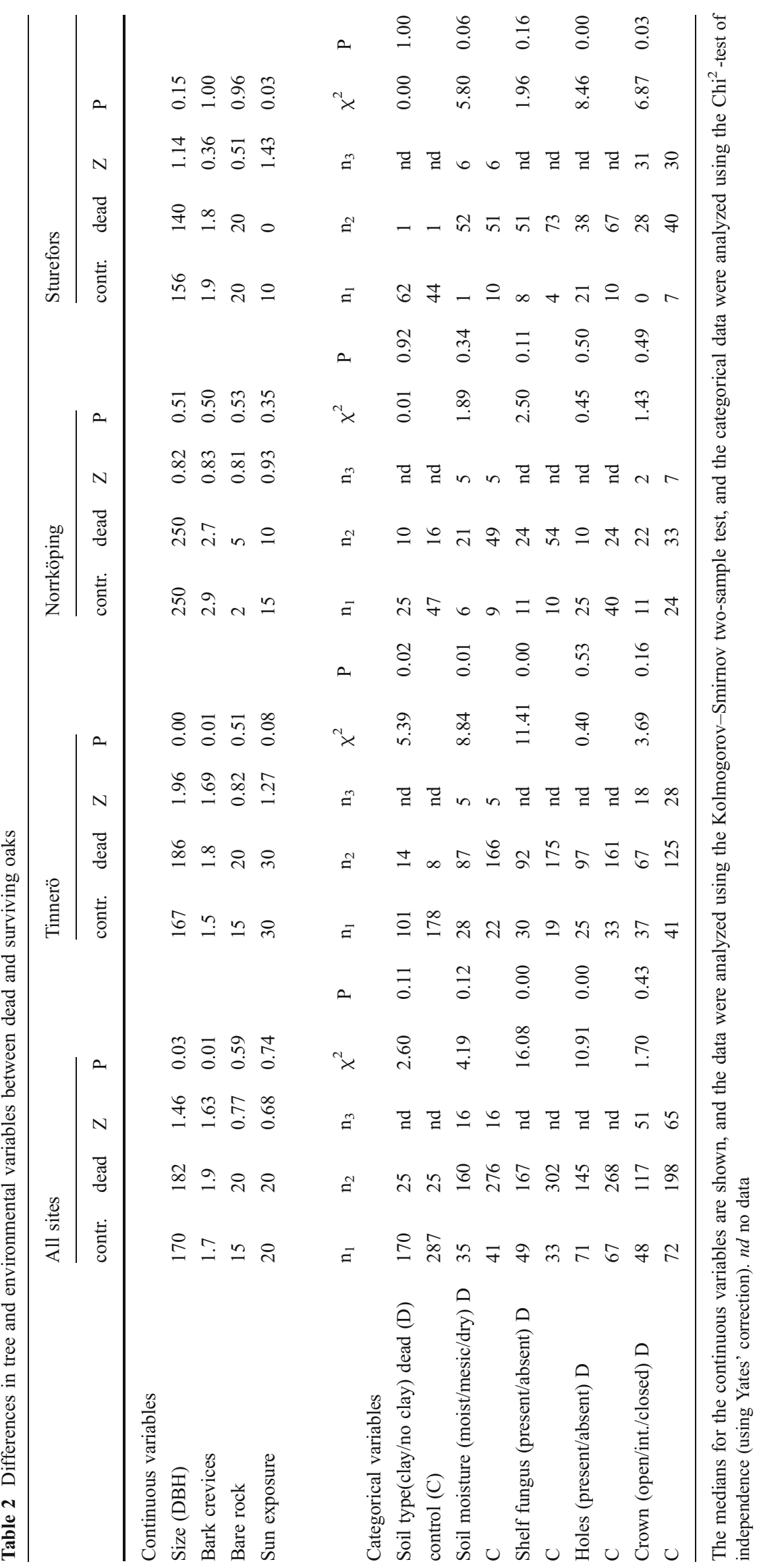




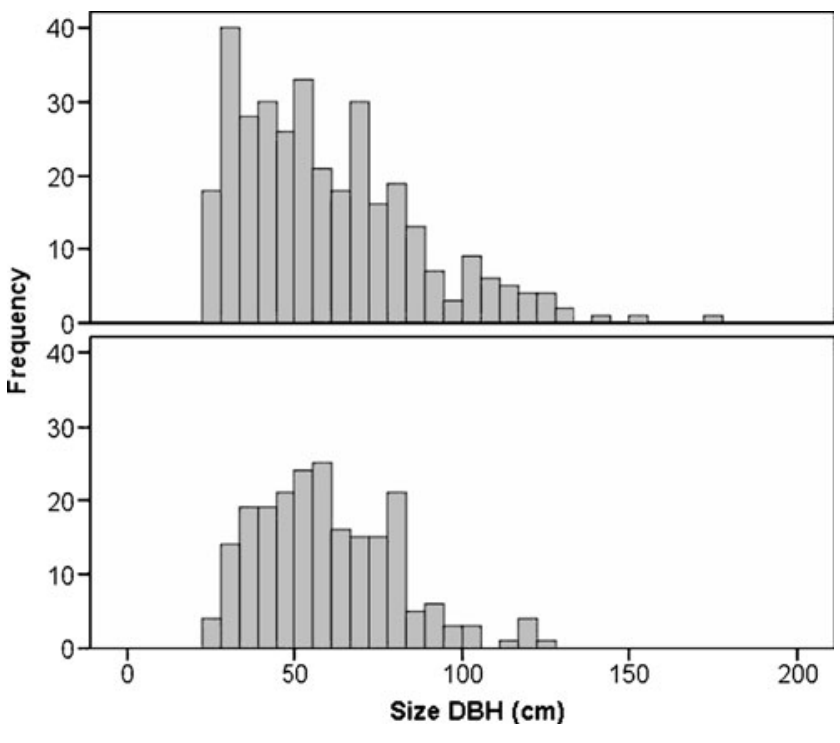

Fig. 1 Size distribution (DBH) of control (upper) and dead (lower) oaks

growth rate (Fig. 3). Several more or less pronounced growth depressions were observed over time when studying data covering the final 100 years of the trees' life histories. While Tinnerö and Norrköping showed a distinct period of reduced growth over the years preceding death, the trend for Sturefors was somewhat more obscure. The length of the growth depression varied among the sites, with Tinnerö and Sturefors having a relatively short time period of reduced growth compared with the decade-long process illustrated by Norrköping. Multiple chronological clustering

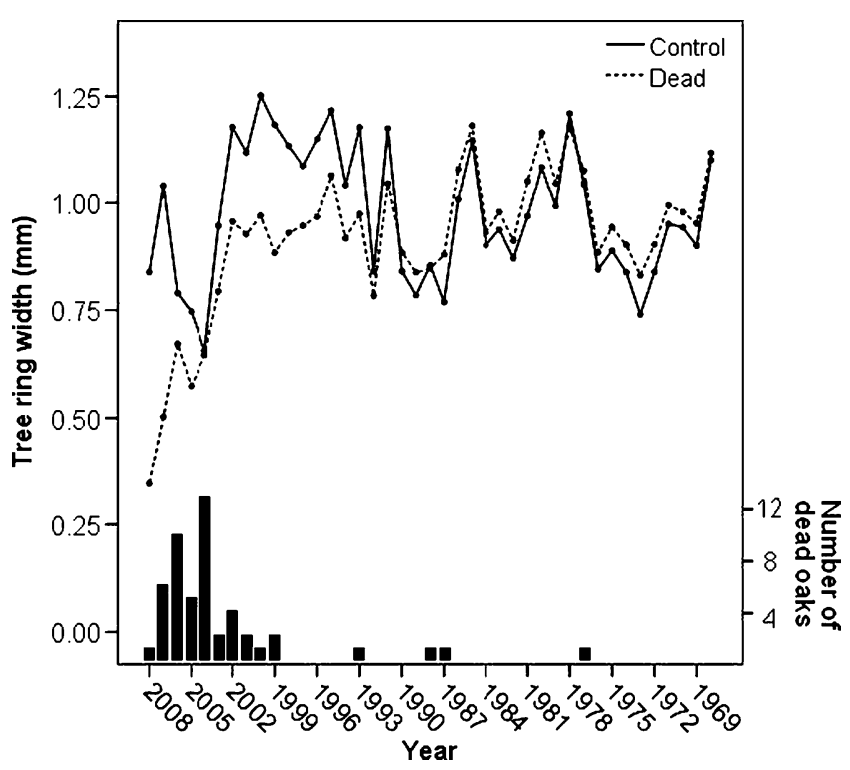

Fig. 2 Mean chronologies of control and dead oaks. Trees contributing to the dead tree chronology decrease with time. Two main breakpoints were detected at 1992 and 1989, using multiple chronological clustering. Bars represent the frequency of dead oaks each year

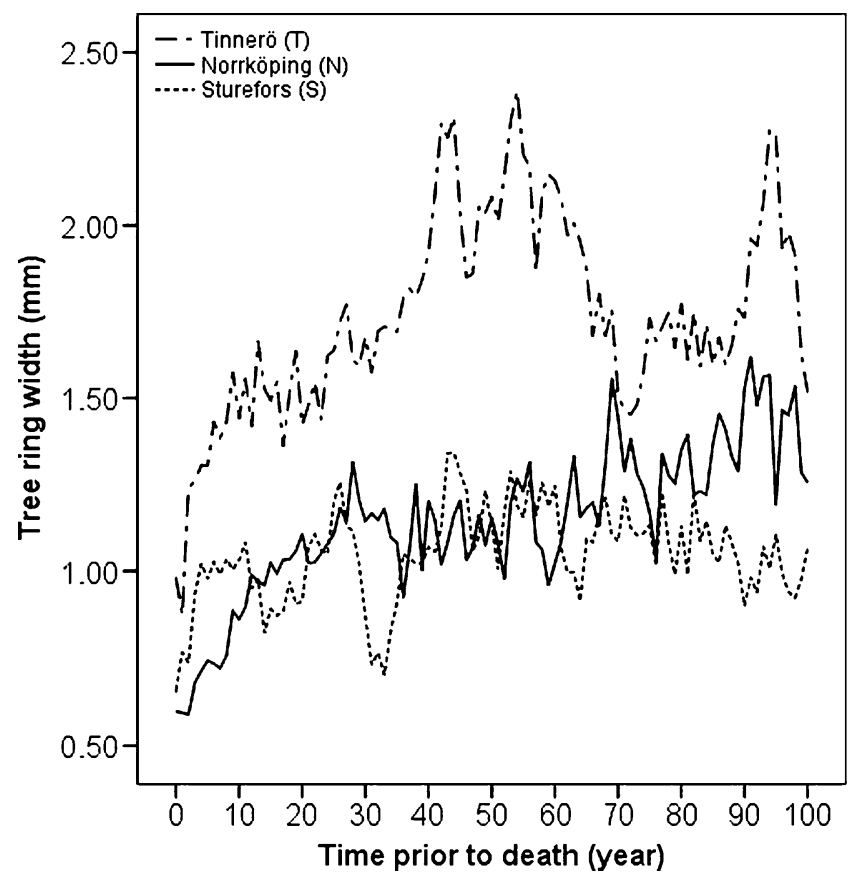

Fig. 3 Mean chronologies of dead trees' ring widths on a time-priorto-death scale at the three sites $\left(n_{T}=26, n_{N}=7, n_{S}=14\right)$

showed main breakpoints at 5 years prior to death for Tinnerö, 1 year prior to death for Sturefors, and 25 years prior to death for Norrköping $(\alpha=0.005)$.

\subsection{Influence of climatic factors}

Three positive $(1963,1967,1985)$ and two negative (1965, 2004) extreme pointer years were detected for the time period 1961-2006 (Fig. 4). In addition, the years 1966 and 1992 were close to threshold, set for negative pointer years (Fig. 4). These years had absolute intensity values of $>25$ and were represented by high-intensity values at all three sites. To determine how climatic factors influence oak growth, correlation analyses were performed on pointer year intensity values and temperature/precipitation data the corresponding and previous year. Only those 20 years showing the greatest absolute intensity values were included in the analysis, in order to minimize signal noise caused by factors other than the weather (Table 3). Pearson correlation coefficients of pointer year intensity values and temperature/precipitation are shown for previous year's August to current year's December (Fig. 5). Previous year's October temperature $(r=0.508$, $p=0.022)$ and September precipitation $(r=0.463, p=0.040)$ correlated positively with oak growth. When pooling several months, precipitation during the period August-October the previous year $(r=0.527, p=0.017)$ and March-June the current year $(r=0.480, p=0.032)$ corresponded positively to tree growth. 


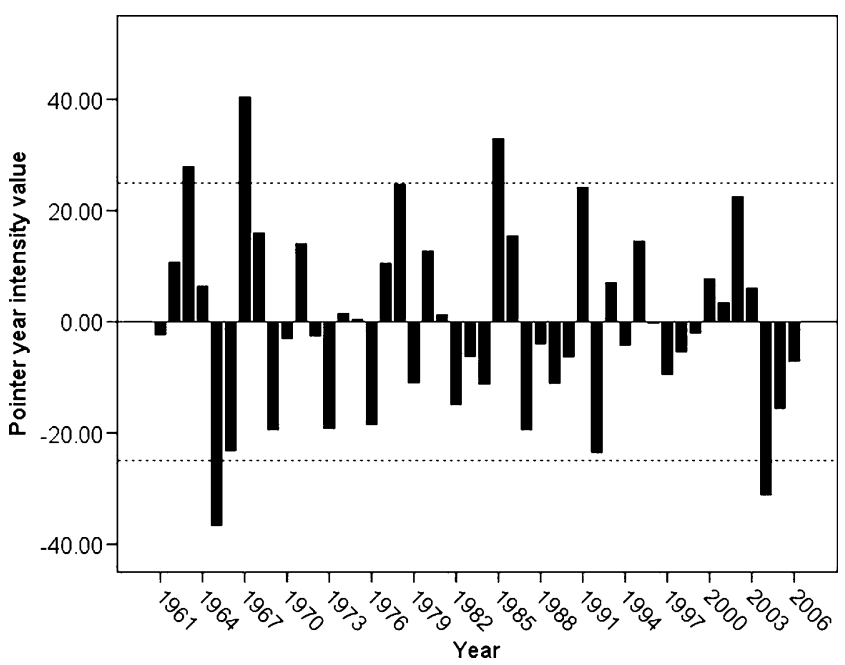

Fig. 4 Pointer year intensity values for the time period 1961-2006, data from all sites pooled. Dashed lines at intensity values \pm 25 represent the threshold for extreme pointer years

\section{Discussion}

\subsection{Impact of climatic factors on tree growth}

Despite an inconsistency in years identified as pointer years among European reports, the most extreme pointer years presented in this study corroborated results from other studies. Three positive $(1963,1967,1985)$ and two negative (1965, 2004) extreme pointer years were found. The year 1965 is reported as a negative pointer year for oak stands in southern Sweden (Drobyshev et al. 2008a) as well as for trees in a study compiling numerous sites across central Europe (Neuwirth et al. 2007). The latter authors also identify 1967 as a positive pointer year, in line with results from another study from western France (Lebourgeois et al. 2004). The years 1978,

Table 3 Years with markedly wider or narrower tree-ring width compared with neighboring tree rings calculated as absolute intensity values (see Methods)

\begin{tabular}{|c|c|c|c|c|c|}
\hline \multicolumn{3}{|c|}{ Positive } & \multicolumn{3}{|c|}{ Negative } \\
\hline Year & Intensity & (n) & Year & Intensity & (n) \\
\hline 1967 & 40.4 & 94 & 1965 & -36.6 & 94 \\
\hline 1985 & 32.9 & 93 & 2004 & -31.1 & 63 \\
\hline 1963 & 27.9 & 94 & 1992 & -23.5 & 91 \\
\hline 1978 & 24.7 & 93 & 1966 & -23.2 & 94 \\
\hline 1991 & 24.1 & 92 & 1969 & -19.4 & 94 \\
\hline 2002 & 22.5 & 91 & 1987 & -19.3 & 92 \\
\hline 1968 & 16.0 & 94 & 1973 & -19.1 & 94 \\
\hline 1986 & 15.4 & 92 & 1976 & -18.5 & 93 \\
\hline 1995 & 14.5 & 91 & 2005 & -15.6 & 54 \\
\hline 1971 & 14.0 & 94 & 1982 & -14.8 & 93 \\
\hline
\end{tabular}

Years in bold are represented by high-intensity values at all sites
1991, and 1992 were found just beneath the threshold defining extreme pointer years in the present study, but are presented as strong pointer years in other reports: 1978 (Kelly et al. 2002; Lebourgeois et al. 2004), 1991 (Lebourgeois et al. 2004), and 1992 (Drobyshev et al. 2008a). The overall resemblance among pointer years presented in this and other European studies was, however, rather low.

Precipitation seemed to have a greater influence on tree growth than temperature and correlated positively for most part of the year. In addition to precipitation previous year's
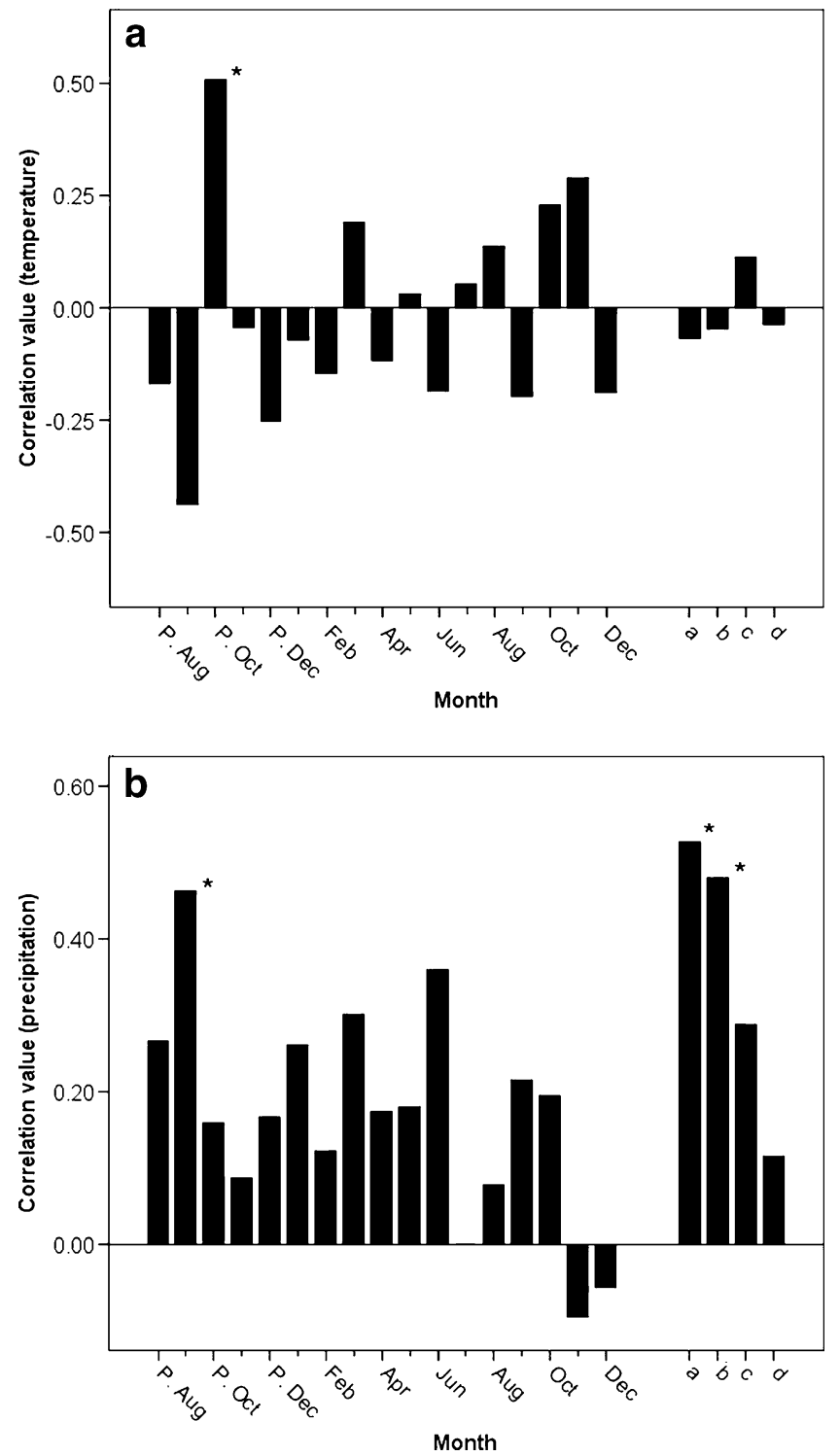

Fig. 5 Coefficients of correlation for pointer year intensity values and a temperature and $\mathbf{b}$ precipitation. The analyses were based on those 20 years showing the maximum absolute intensity vales. Previous year's months are marked " $P$ ". Small letters at the right represent pooled months; a Previous year August-October, b current year March-June, c current year July-October, d current year JanuaryFebruary and November-December. Significant correlations at a $5 \%$ level are marked with asterisk 
September, the time period August-September previous year, as well as the period March-June the current year, were of significant importance for oak growth. This is mainly in line with results from other studies, stressing the importance of precipitation during previous year's autumn (Freidrichs et al. 2008; Drobyshev et al. 2008a) as well as spring and early summer precipitation in the current year (Bednarz 1990; Lebourgeois et al. 2004; Čufar et al. 2008). Somewhat surprisingly was the indication that the amount of precipitation during July had no effect on oak growth, since several European studies assign June and July precipitation as essential controlling factors for oak growth (Pilcher and Gray 1982; Rozas 2002; Drobyshev et al 2008a). Temperature correlated rather poorly to tree growth, with an exception of previous year's September and October values. A positive impact of high temperatures during previous year's late growing season can be explained by an extended period of physiological activity at the end of the growing season (Drobyshev et al. 2008a). It has been shown that the concentration of sucrose in leaves of red oak (Quercus rubra L.) drastically drops in late October, as a translocation to the stem takes place (Xu and Griffin 2006). Warmer October temperatures might therefore enable more carbohydrates to be relocated, resulting in more available energy reserves during the following growing season.

Weather during the winter months exerted a weak influence on the growth, in line with results from another study performed on oak stands in southern Sweden (Drobyshev et al. 2008a).

\subsection{Influence of water availability on oak vigor}

To determine whether the oak mortality in this study could be attributed to a specific environmental factor, the cores were analyzed for a possible common year for which the majority of the trees destined to die started to express reduced growth. When studying averaged chronologies of dead and control trees, 1992 was identified as the offset year of a growth depression affecting the dead trees also supported when using multiple chronological clustering. Weather data showed that the precipitation for 1992 was well below normal for most part of the year and in combination with an extremely high summer temperature, the oaks were most likely under a severe drought stress during most part of the growing season (Karlstöm 1993; Bréda and Badeau 2008). The results show that water availability is a major driver of interannual changes in growth, but not alone able to induce tree death.

Site-specific factors influencing the water availability of oaks might affect the tree's ability to withstand drought events. However, no distinct pattern applicable for all sites was found, in the present study, when analyzing soil structure and moist conditions.
4.3 Additional factors contributing to a reduced vigor of the oaks

Drought stress as a single factor is not considered strong enough to cause the actual death of a tree, but rather acts as a weakening component, making the tree more susceptible to other stress factors (Thomas et al. 2002; Thomas 2008). Therefore, the drought in 1992 is believed to be the triggering factor of the oak mortality examined in this study, but additional factors presumably contribute to the death of the trees. A particularly strong reduction in growth was detected for the averaged chronologies of both dead and living trees in 2003-2004. These years had a somewhat higher precipitation than normal and a temperature around normal (Karlström 2003; Karlström 2004), wherefore the growth reduction is not considered to be weather-related. Instead, the reduction in growth is believed to be the result of a combination of a defoliation caused by the European oak leaf roller (Tortrix viridana Linnaeus 1758), taking place in Tinnerö 2002-2003, and a mildew infection of the replacement shoots during the following year (pers. comm. Anders Jörneskog, Linköpings kommun, Sweden). Several oak declines have been attributed to insect attacks (Rubtsov 1996) in combination with mildew infections (Marcais and Bréda 2006) or extreme drought events (Breda and Badeau 2008).

Defoliations cause extensive losses of photosynthates of trees, because the assimilating leaf area becomes heavily reduced. Trees do, however, generally have substantial carbon reserves, allowing them to regenerate the reduced foliage by developing new replacement shoots which over time can compensate for the lost energy. Trees already suffering from reduced carbohydrate reserves when becoming defoliated might, however, not have the resources needed for the formation of a new regeneration of leaves; hence, the depletion of carbohydrates will continue (Thomas et al. 2002). A recovery in growth following the insect outbreak and the mildew infection in this study was detected only for the control trees, indicating that trees weakened from the drought in 1992 were less resistant to the insect attack and did not have the energy reserves needed for a recovery.

\subsection{The mortality process}

The length of a growth depression prior to death gives valuable information about the character of the deathinducing event. In this study, a growth depression prior to death was evident for at least $1-5$ years prior to death for Tinnerö and Sturefors and at least 25 years prior to death for Norrköping. This gives support to the proposal of the insect outbreak and mildew infection as the ultimate mortality factor causing a relatively rapid death of the oaks 
in Tinnerö and most likely also in Sturefors. The more extended mortality process illustrated by trees growing in Norrköping suggests a rather long-term stress, such as climate, as the triggering factor of the oak decline. A time lag in the mortality-inducing event and the actual death of the oak is supported by several other studies (Pedersen 1998; Marçais and Caël 2001; Drobyshev et al. 2007; Haavik et al. 2008), indicating that oak mortality should be seen as a several-year-long process most likely caused by a complex interplay among several stress factors acting together over time (Thomas 2008). The fact that only those trees remaining relatively unaffected by the drought in 1992 recovered from the defoliation and mildew infection emphasizes the importance of a tree's history when examining mortality patterns.

Dead trees in Sturefors were characterized by being exposed to less sunshine and having more closed crown silhouettes, indicating that also poor growing conditions could be seen as a long-term stress making the trees less efficient to withstand additional stress events. Oak mortality rates have been shown to correlate with stand density, emphasizing the effect of competitive interactions on oak mortality (Drobyshev et al. 2008b). Higher frequencies of shelf fungus and cavities were observed among the dead trees when pooling all sites. However, it is not possible to differentiate if this is a result of the decreased vigor of the trees, or the actual cause of it.

Acknowledgments We thank Thure Gabriel Bielke for permission to study oaks on his land. We are also grateful to Igor Drobyshev and Lars-Åke Larsson for providing valuable advice and Sylvia Pardonnet for french translation.

\section{References}

Barklund P (2002) Ekskador i Europa. Rapport 2002:1. Skogsstyrelsens förlag, Jönköping. ISS: 1100-0295. In Swedish

Bednarz Z (1990) The influence of temperature and precipitation on ring widths of oak (Quercus robur L.) in the Niepolomice forest near Cracow, Southern Poland. Tree-ring Bull 50:1-10

Bréda N, Badeau V (2008) Forest tree responses to extreme drought and some biotic events: towards a selection according to hazard tolerance? C R Geosciences 340:651-662

Čufar K, De Luis M, Zupancic M, Eckstein D (2008) A 548-year long tree-ring chronology of oak (Quercus spp.) for SE Slovenia and its significance as dating tool and climate archive. Tree-ring Res $64: 3-15$

Davies ZG, Tyler C, Stewart GB, Pullin AS (2008) Are current management recommendations for saproxylic invertebrates effective? A systematic review. Biodivers Conserv 17:209-234

Dreyer E (1994) Water stress, xylem dysfunctions and dieback mechanisms in European oak trees. STEP Research Programme CT90 0050C, Final Report. Champenoux, France: INRA Nancy

Drobyshev I, Linderson H, Sonesson K (2007) Temporal mortality pattern of pedunculate oaks in southern Sweden. Dendrochronologia 24:97-108
Drobyshev I, Niklasson M, Eggertsson O, Linderson H, Sonesson K (2008a) Influence of annual weather on growth of pedunculate oak in southern Sweden. Ann For Sci 65:512

Drobyshev I, Niklasson M, Linderson H, Sonesson K, Karlsson M, Nilsson SG, Lanner J (2008b) Lifespan and mortality of old oaks-combining empirical and modelling approaches to support their management in Southern Sweden. Ann For Sci 65:401

Esseen PA, Glimskär A, Ståhl G, Sundquist S (2007) Field instructions for the national inventory of the landscape in Sweden. SLU, Department of Forest Resource Management. www.resgeom.slu.se/resana/NILS/Publikationer/NILS_manual_ fält_2007_English.pdf

Friedrichs DA, Buntgen U, Frank DC, Esper J, Neuwirth B, Loffler J (2008) Complex climate controls on 20th century oak growth in Central-West Germany. Tree Physiol 29:39-51

Glimskär A, Bergman K-O, Claesson K, Sundquist S (2007) Fältinstruktion för fjärilar, humlor, grova träd och lavar i ängsoch betesmarker. NILS 2007. SLU, Institutionen för skoglig resurshushållning och geomatik. In Swedish. www.resgeom.slu. se/resana/NILS/Publikationer/NILS_manual_ÄoB_\%202007.pdf

Haavik LJ, Stephen FM, Fierke MK, Salisbury VB, Leavitt SW, Billings SA (2008) Dendrochronological parameters of northern red oak (Quercus rubra L. (Fagaceae)) infested with red oak borer (Enaphalodes rufulus (Haldeman) (Coleoptera: Cerambycidae)). For Ecol Manag 225:1501-1509

Hannah L, Carr JL, Lankerani A (1995) Human disturbance and natural habitat: a biome level analysis of a global data set. Biodivers Conserv 4:128-155

Heinrich I, Weidner K, Helle G, Vos H, Banks JCG (2008) Hydroclimatic variation in Far North Queensland since 1860 inferred from tree rings. Palaeogeogr Palaeoclimatol Palaeoecol 270:116-127

Jonsson U, Jung T, Sonesson K, Rosengren U (2005) Relationships between health of Quercus robur, occurrence of Phytophthora species and site conditions in southern Sweden. Plant Pathol 54:502-511

Jung T, Blaschake H, Osswald W (2000) Involvement of soilborn Phytophthora species in Central European oak decline and the effect of site factors on the disease. Plant Pathol 49:706-718

Karlström CE (1993) 1992-Torka, skyfall och rekordsnö. Väder och vatten, SMHI 1: 2-7. In Swedish

Karlström CE (2003) Årets väder 2003. Väder och vatten, SMHI 13. In Swedish

Karlström CE (2004) Årets väder 2004. Väder och vatten, SMHI 13. In Swedish

Kelly PM, Leuschner HH, Briffa KR, Harris IC (2002) The climatic interpretation of pan-European signature years in oak ring-width series. Holocene 12:689-694

Kinney KK, Lindroth RL, Jung SM, Nordheim EV (1997) Effects of $\mathrm{CO}_{2}$ and $\mathrm{NO}_{3}$ - availability on deciduous trees: phytochemistry and insect performance. Ecology 78:215-230

Lebourgeois F, Cousseau G, Ducos Y (2004) Climate-tree-growth relationships of Quercus petraea Mill. stand in the Forest of Bercé ("Futaie des Clos", Sarthe, France). Ann For Sci 61:361372

Legendre P, Dallot S, Legendre L (1985) Succession of species within a community: chronological clustering, with applications to marine and freshwater zooplankton. Am Nat 125:257288

Marcais B, Bréda N (2006) Role of an opportunistic pathogen in the decline of stressed oak trees. J Ecol 94:1214-1223

Marçais B, Caël O (2001) Relation between Collybia fusipes root rot and growth of pedunculate oak. Can J For Res 31:757-764

Neuwirth B, Esper J, Schweingruber FH, Winiger M (2004) Site ecological differences to the climatic forcing of spruce pointer 
years from the Lötschental, Switzerland. Dendrochronologica 21:69-78

Neuwirth B, Schweingruber FH, Winiger M (2007) Spatial patterns of central European pointer years from 1901 to 1971. Dendrochronologia 24:79-89

Pedersen BS (1998) The role of stress in the mortality of Midwestern oaks as indicated by growth prior to death. Ecology 79:79-93

Pilcher JR, Gray B (1982) The relationships between oak tree growth and climate in Britain. J Ecol 70:297-304

Ranius T, Niklasson M, Berg N (2009) Development of tree hollows in pedunculate oak (Quercus robur). For Ecol Manag 257:303-310

Rozas V (2002) Detecting the impact of climate and disturbances on tree-rings of Fagus sylvatica L. and Quercus robur L. in a lowland forest in Cantabria, Northern Spain. Ann For Sci 58:237-251

Rubtsov VV (1996) Influence of repeated defoliations by insects on wood increment in common oak (Quercus robur L). Ann For Sci $53: 407-412$

Thomas FM (2008) Recent advances in cause-effect research on oak decline in Europe. CAB Reviews: Perspectives in Agriculture,
Veterinary Science, Nutrition and Natural Resources 2008 3, No 037

Thomas FM, Blank R (1996) The effect of excess nitrogen and of insect defoliation on the frost hardiness of bark tissue of adult oaks. Ann For Sci 53:395-406

Thomas FM, Hartmann G (1996) Soil and tree water relations in mature oak stands of northern Germany differing in the degree of decline. Ann For Sci 53:697-720

Thomas FM, Blank R, Hartmann G (2002) Abiotic and biotic factors and their interactions as causes of oak decline in Central Europe. For Pathol 32:277-307

Xu CY, Griffin KL (2006) Seasonal variation in the temperature response of leaf respiration in Quercus rubra: foliage respiration and leaf properties. Funct Ecol 20:778-789

Vedin H (2004) Östergötlands klimat. Väder och vatten 10. In Swedish

Wiles GC, Calkin PE, Jacoby GC (1996) Tree-ring analysis and Quaternary geology: principles and recent applications. Geomorphology 16:259-272 